\title{
Homeschool in Malaysia: A Foresight Study
}

\author{
Ng Kim-Soon ${ }^{1}$, Abd Rahman Bin Ahmad ${ }^{1}$, Muhammad Ibrahim Bin Sulaiman ${ }^{1} \&$ Ng Mei Xin Sirisa ${ }^{2}$ \\ ${ }^{1}$ Faculty of Technology Management and Business, Universiti Tun Hussein Onn Malaysia, Malaysia \\ ${ }^{2}$ Faculty of Arts and Social Science, Universiti Tunku Abdul Rahman, Malaysia \\ Correspondence: Ng Kim-Soon, Faculty of Technology Management and Business, Universiti Tun Hussein Onn \\ Malaysia, Malaysia. E-mail: ksng@uthm.edu.my
}

Received: March 31, 2015 Accepted: May 8, 2015 Online Published: September 28, 2015

doi:10.5539/ies.v8n10p163 URL: http://dx.doi.org/10.5539/ies.v8n10p163

\begin{abstract}
Homeschooling in Malaysia is a form of alternative education that emphasizes quality education based on moral values and beliefs while strengthening family bonds. This alternative form of education is being practiced by a growing number of families in Malaysia. As such, the Ministry of Education has given the green light for intending parents who wish to homeschool their children to do so with prior permission from the Ministry. Local parents homeschool their children for various reasons. This study was undertaken to foresight the trends of parents who homeschool their children in Malaysia. A mixed approach was used in this study. The data collected was analyzed by using impact uncertainty analysis to foresight homeschool in Malaysia. Data was collected from 30 parents who homeschool in Malaysia and 4 of them were also interviewed. Parent left mainstream schooling is mainly due to inadequate curriculum or syllabus, social issues among students, an adverse school environment and conflicting values in the mainstream's schools. The key drivers of homeschool in Malaysia are social issues among students and the education syllabus offered. This research work foresighted the drivers of homeschooling and provided possible scenarios of future of homeschool in Malaysia. Discussion and recommendations were provided.
\end{abstract}

Keywords: homeschool, trend of homeschool, foresight, driver of change

\section{Introduction and Research Background}

Homeschooling is an educational practice that is fully supervised by parents at regular schooling and it takes place on the same day as the public schools (Rajamony, 2008; Ray, 2000). The homeschool education is an alternative way of education in Malaysia. It is new, the knowledge and its existence as of today can be considered as uncommon. The choice of homeschool by the parents is due to the belief of that it is the parents' responsibility to determine the best form of education for their children (Ray, 2009). Thus, some Malaysian parents with such awareness and way of thinking choose to homeschool their children with diverse curriculum of their preference.

In pursuit of having Malaysia's education gain comprehensive knowledge of national education, the need to direct more attention in understanding the education of homeschooled children is as important as other styles of education that are present today. These studies generate a wealth of information applicable to broaden the educational settings. Scholars interested in cognitive development may gain important insights from unschooling families, who tenaciously pursue child-led learning (see Holt, 1981). The tailored education which emphasizes on the fulfillment of the child's pace of learning would be a benefit to other parents and the education system itself.

The practice in which the education of the child is clearly parent-controlled or parent-directed during the mainstream-school hours during the mainstream-school days of the week defines homeschool (Ray, 2000). It can be seen as a temporary or a permanent alternative to the education which is provided by the state or by private schooling. Parents are opting for home schooling in rising numbers in many countries (Ray, 2000). In Malaysia, the home schooling phenomena transited two phases. The first phase was prior to the year 2003 and the second phase was after 2003 when the Compulsory Education Act (2003) was implemented. Prior to 2003, the Minister of Education allowed parents to home school without restrictions (The Star, Malaysia, 2002). But since the year 2003 onwards when the Compulsory Education Act was implemented, home schooling was only allowed with prior permission from the Ministry of Education. According to Rajamony (2008), the actual number of 
homeschoolers in Malaysia is less than the number of the approved homeschoolers by the Ministry of Education.

Home schooling involves the use of a self-determined curriculum. The curriculum may be bought off the shelf or one the parent build it up by combining the best from available syllabuses. The curriculum may be selected based on religious inclinations or pedagogical reasons (Basham, 2001). The internet, personal computer technology and the readily available resources including support groups and educational material have made home schooling easier (Aurini \& Davies, 2005; Basham et al., 2007). With internet and online chatting, the homeschooling parents are able to establish their own circles, homeschooling websites, forums, etc. (He, 2012). They gathered together on Internet, sharing homeschooling resources, organizing online discussions among parents. They also held off-line activities for parents and homeschooling children. However, despite all these delighted developments of homeschooling, in China there has not been a single specific regulation for homeschooling, or any official organizations or supportive group so far $(\mathrm{He}, 2012)$. Home schooling allows innovative learning options. In Alaska, teachers in Juneau work with students located at all over the state, staying in touch by mail, telephone, and through occasional home visits. In California, children can enroll in an independent-study program through a public school then base their studies in their own homes. Washington and Iowa require public schools to enroll children on a part-time basis if they apply (Lines, 1995).

Homeschool is a choice among parents, although it is an alternative and not a mainstream education in Malaysia. It is still growing with all kind of syllabus and curricular module brought into Malaysia by homeschooler's parents and private schools that offer homeschool education. The number of parents' homeschooling in Malaysia is close to 5,000 children (Bajunid, 2002). This number is still growing as issues of mishandle of students cases, social problem in mainstream school, inefficiency in teaching and learning and practice in the mainstream school that is not aligned with the family's belief has led to the increase of homeschool population in Malaysia.

Although the homeschooling trend is growing in popularity in the United States, there is lacking of empirical research work focusing in the area (Green \& Hoover-Dempsey, 2007). Reviews on previous literatures show that there are scant number of studies that focus on homeschool in Malaysia. Homeschool being quite new phenomena in Malaysia and in this case, there seems to be a need for a clear understanding and to be explored. Underlying issues here include the unclear direction of homeschool in Malaysia. What is driving the homeschooling trend and how is it being perceived in Malaysia? Research questions of this study are: 1 . What is the trend of homeschooling in Malaysia? 2. What are the homeschool drivers of change and the perceptions towards national education system? 3. What will be the future trend of homeschooling in Malaysia by the year 2025? It follows that the research objectives of this study are: 1) To study the trend of homeschooling in Malaysia. 2) To study the homeschool drivers of change and perception towards national education system and; 3) To study the future trend of homeschooling in Malaysia by the year 2025.

This research is a foresight case of homeschool trends in Malaysia by the year 2025. And it will determine the impact of homeschool to the students and the driving factors of continuous choice of homeschool education in a family. Since there are limited number of studies that focus on homeschool in Malaysia with lack of study on foresight of it, this study can provide some contribution in term of additional knowledge of this subject in the Malaysian context. The lack of study on this matter would be invaluable as the advantage and disadvantage of homeschool especially for Malaysians in a multicultural environment would substantially cover the issues of today's Malaysian parents' preference in education of our future generations. Thus, this foresight study is foreseen to engage in these new phenomena in Malaysia's education and to aid the responsible parties in their debate of direction of homeschool education. The respondents are the family that home school their children. This specific group of parents have high influence of society. They include bloggers and also parents who had studied abroad and are able to compare the different ways and style of education offered. In Malaysia, majority of the home schoolers exist in Kuala Lumpur. Thus, in this study, the respondents are from Kuala Lumpur.

\section{Literature Review}

The importance of the direction of homeschool in Malaysia and any other countries are crucial to be studied as it is the guidelines of where and when the homeschooler could improvise for the sake of their children's education in the future.

The education system in Malaysia formally involves nine types of schools namely national schools, national type schools, religious schools, school preacher, a typical model school, a typical school education, vocational and technical schools, and full boarding school (Ministry of Education, 2010). The education system in Malaysia is dynamic along with the development and progress of the age. Education in Malaysia is overseen by one government ministry. The Ministry of Education handles matters pertaining to pre-school, primary school, secondary school, post-secondary school and tertiary education. 
Although education is the responsibility of the federal government, each state has an Education Department to coordinate educational matters in its territory. The main legislation governing education is the Education Act of 1996. Primary public education in Malaysia begins at age seven in National or Vernaculars Primary Schools and lasts for six years, referred to as Year 1 to 6 . Year 1 to Year 3 are classified as Level One while Year 4 to Year 6 are considered as Level Two. Students are promoted to the next year regardless of their academic performance. Public secondary education in Malaysia is provided by National Secondary Schools. The National Secondary Schools use Malay as the main medium of instruction. English is a compulsory subject in all schools. Since 2003, Science and Mathematics had been taught in English, however in 2009 the government decided to revert to using Malay starting from the year 2012. After the SPM (Malaysian School Certificate of Education), students from public secondary school would have a choice of either studying Form 6, Foundation in Science or Arts for entrance to University in private university or the matriculation (pre-university). If they are accepted to continue studying in Form 6, they will also take the Sijil Tinggi Persekolahan Malaysia (which is usually called as STPM) or Malaysian Higher School Certificate examination (its British equivalent is the General Certificate of Education 'A' Levels examination or internationally, the Higher School Certificate). SPM and STPM are regulated by the Malaysian Examinations Council.

Homeschooling is an educational practice that is fully supervised by parents at regular schooling and took place on the same day as the public schools (Rajamony, 2008; Ray, 2000). Parents choose to engage in homeschool because they want to educate and monitor their children with their own reference. At the same time they do not marginalize academic excellence to continue the survival of their children to meet the demands of society in gaining employment. Selection of an appropriate curriculum could be compassed by religious inclination or aspects of pedagogy (Rajamony, 2008). Parents asserted that it is their responsibility to determine the best form of education for their children, and not the responsibility of other parties (Ray, 2009).

The choice narrated by parents who homeschooled their children were classified and noted by two elements of styles, the pedagogy, which can be simplified as earth based or science based, and ideologues which also can be simplified as heaven based or religion based (see Van Galen, 1988). It diverts nationwide research works based on these two opposite teaching factors and styles. Homeschooling parents appeared to be strongly motivated by personal motivators identified in the general parental involvement literature, such as an active role construction and a strong sense of efficacy for helping the child learn, than by other explanations for homeschooling, such as parents' beliefs about the values, content, adequacy, and methods of public school education (see Ice \& Hoover-Dempsey, 2010). Most of the fundamental homeschoolers that set the essence of homeschooling were fundamentalist Christian, which also can be classified as religion as core in one's way of educating, (Ray, 1997; Van Galen, 1988) as they observe the clearance of giving the nature of obedience to Lord preach biblically. Homeschooling allows parents from all of these groups to integrate their particular religious beliefs into their children's educations (Ray, 1997; Rudner, 1999; Van Galen, 1988).

Rajamony (2008) conducted a qualitative study of five Malaysian families who homeschooled their children. The findings showed that parents choose to homeschool them due to the content of the public school curriculum which is not convincing enough. Parents were also concerned about what they saw as inefficiency in teaching and learning and practice in the mainstream school that is not aligned with the family's belief.

Studies of diverse groups of elementary and middle school students have suggested that role activity beliefs do influence parents' decisions about becoming and being involved in their children's education involvement (e.g., Chrispeels \& Rivero, 2001; Drummond \& Stipek, 2004; Grolnick et al., 1997; Hoover-Dempsey et al., 2005; Sheldon, 2002). Green and Hoover-Dempsey (2007), for example, reported that most homeschool parents had particularly strong role activity beliefs related to involvement in their children's education. Children's interest in learning for their own sakes, in contrast with learning for the external consequences or rewards it may yield (Ryan \& Deci, 2000). This triggers the interest of parents to experiment on how to push and mold their children to their full potential. This would result in shaping of inner self and distinct characteristic rather than what the mainstream education could offer to the children in their growing phase.

The latest issues related with homeschool in the period of 2008 till 2014 include parents motivation (Walter et al., 2011), the increasing numbers of homeschoolers (Ray, 2011), hesitation on homeschool (Haugh, 2014), homeschool comprehensive study (Kunzman \& Gaither, 2013) and fundamental challenge (Ross, 2010). These topics were popular and discussed.

There is an increasing numbers of children being homeschooled (Lines, 2000; Russo, 1999; Stevens, 2001). The increase reflects a growing dissatisfaction with formal education (Lyman, 1998) and a growing public acceptance of homeschooling (Lines, 2000). Homeschooling is growing in popularity in the United States (e.g., up from 
850,000 students, or $1.7 \%$ of K-12 students in 1999 -Bielick et al. (2001)-to 1.1 million students, or $2.2 \%$ of K-12 students in 2003-Princiotta et al., 2004). In the United States, homeschooling had been legalized since the year 1993 in all 50 states under the pressure from homeschooling organizations. The exact numbers of home educators in each country are difficult to come by for a variety of reasons. In some countries, children who have never been to school are not required to register with the authorities.

In the United States, the study of ins and outs journal emphasized that the homeschool implemented consisted of two crucial factors. The ins is the motivation from the parents that homeschool and the outs is the level of achievement of the homeschool students. This study showed details of Parents' motivations for homeschooling are not uniformly affected by their education, gender, income, marital status, previous involvement with homeschooling, or political identification. While the results for the outs or the achievements were higher in accordance to several factor which were related to the level of education of the parents, the political view or stands and the type of motivation that drive them to homeschool (see Collom, 2005). Parents that homeschool in U.S were related for having a high level of education or highly educated than parents of non-homeschoolers. Parents gave a wide variety of reasons for homeschooling their children. These reasons included being able to give their child a better education at home, for religious reasons, and because of a poor learning environment at school. Most research works in the past are on determining the whys of parents homeschool their children (see B Boschee \& F. Boschee, 2011). Study shown that the choice of homeschool among parents are linked with the fact that most homeschoolers achieved better results in their entrance examination and test which ultimately brought them to enter known college and strive afterwards.

The common cause of homeschooling from its history was related with religion as studies shows that the awareness of religion in molding their offspring to have the religion essence which these parents are afraid of their children lack of it or not be learned as they were before. Thus, the idea of controlling of what to be taught which would satisfy them technically that the mainstream education offered from the government in their country. In this way, parents are protecting their rights to give as much religion based education. Example, Muslim turns to homeschool in order to protect their children from drug using and also their daughters from bad image dresses, the bad talk or swearing, and low respects level to their elders, as well to give protection from upcoming prejudice (MacFarquhar, 2008). These parents feel that traditional schools, especially mainstream schools, fail to teach the importance and the respect their families' values and that these schools sometimes lack and lost in its module or curricula which in their opinion contradict with their belief (Ray, 1997; Rudner, 1999; Van Galen, 1988). Thus, the idea of confronting the social problems which were drugs, sexual activity, and also sexual orientation to be covered by the hand of the parents, which brought to way of homeschool in order to protect their children in this fast changing world. Zhao and Badzis (2014) reported that in mainland China, parents who are motivated to choose homeschool are basically out of concerns and dissatisfied with their educational systems which is exam-oriented and others due to religion reason. A large group of pedagogically-oriented parents chooses homeschooling to avoid the hegemonic and inequitable facets of traditional schools. Schools, such parents contend, legitimize certain knowledge and cultures while excluding others (Van Galen, 1988). The idea of building or nurturing their children to be their true self rather than let the public school rank and standardize their children, which worries them as so they feel traditional schools fail to encourage independent thinking (Franzosa, 1991) and stifle their children's creativity and growth (Gibbs, 1994).

\section{Methodology}

This section discusses the methodology of this study. It includes the research design, data collection, and data analysis.

The foresight methodology that was used in the study is similar to that used by Kim-Soon et al. (2014). It included the use of survey questionnaire and structured interview questionnaire. This is a qualitative research to answer the research questions and objectives.

This study is conducted in Kuala Lumpur, as the majority of homeschoolers are found there in Malaysia. A sample of 30 parents that homeschool their children were selected on a random basis and among them 4 parents were interviewed.

The data collections of this study relies on the Phase 1: base data collection (secondary data) and Phase 2: main data collection (primary data). The primary data was collected through interviews and questionnaires. The interview questions are in the form of semi-structured. The secondary data was collected through books, reports, journals and website. In this stage, it involved the process of collecting evidence about current and future situations of homeschool in Kuala Lumpur and the Malaysian Ministry of Education. First, secondary data was collected by using STEEPV analysis. The outcomes of Phase 1 are the pre-determined list of drivers. These 
drivers were then used to develop the questionnaires and interview questions. Phase 2 is on the main data collection. A mixed approach consist of questionnaire and interviewing sessions were done by using STEEPV analysis and covered the overall environment which are current and future situations. The gathered results and answers were synthesized to search the key drivers, and these key drivers were used to create and to predict the future scenarios of homeschool in Malaysia. In Phase, the data were analyzed. The scenario analysis and scenario building were done to foresight homeschooling.

The drivers of change are the key factors that support the important trends and issues. These drivers were identified using the STEEPV analysis that determine the uncertain terms of possible development and implication. The drivers are the trends, technologies and issues that act as driving forces for future changes.

The second step in scenario building is the analysis of the impact-uncertainty. This step was used to determine the uncertainties in the determination of future of homeschooling in Malaysia. Then, the uncertainty axis was used to find the most uncertain drivers that might have the higher influence over the future of homeschooling. A 2X2 approach was used as only 2 key drivers are the most uncertain and most impactful drivers that influence the future. Four scenarios were produced from this approach.

\section{Findings and Analysis}

All the data gathered were explained and analyzed in order to achieve the research objectives determined earlier. A total of 4 parents were interviewed and they are also the respondents who answered the survey questionnaire. The total number of duly completed returned questionnaires was 30 .

The age of respondents from various homeschooler's parents that responded to the survey questionnaire are a total of 50 percent ( 15 respondents) of the respondents aged 36-45 years old, 26.7 percent ( 8 respondents) aged 25-35 years old, and 23.3 percent ( 7 respondents) aged $46-55$ years old. The highest respondent frequency distribution of race is the Chinese with a total of 19 person (63.3\%) followed by Malay, 8 person $(26.7 \%)$ and Indian, 3 person (10\%). Most respondents are female with 26 person (86.7\%) while male gender respondents are 4 person $(13.3 \%)$. The highest frequency distribution and percentage are Master level which is 13 person (43.3\%) followed by Degree by 10 person (33.3\%), PHD level by 4 person (13.4\%) and SPM level by 3 person $(10 \%)$.Majority of respondents live in the urban area or a total of 16 person $(53.3 \%)$ while respondents from the suburban area is 14 person (46.7\%). The highest frequency and percentage of the parent's monthly combined income are in a range of RM8001-RM10000 comprise of 12 person $(40 \%)$ followed by the range above RM10001, 9 person (30\%) and income in range of RM6001-RM8000, 6 person (20\%) while the lowest income range recorded is between RM4001-RM6000 which is 3 person (10\%). The highest frequency for the main reason for homeschooling their children is having no faith in the education system. This is with a frequency of 18 person $(60 \%)$ followed by religious belief, frequency of 9 person $(30 \%)$ and flexibility with travel time, with 3 person $(10 \%)$.

Parents scored on a Likert scale of 1 to 5 to indicate the level of agreement of homeschool components. A total of 8 components/items were used to indicate the trend of homeschooling in Malaysia. The highest mean score was the role of parents involved in their children education which was at level of 4.4, followed by religious belief integrated syllabus at level of 3.8 and flexibility of syllabus in homeschooling with a score level of 3.73. The three medium level of mean score are the specific and rigid homeschooling syllabus at 3.23 level, child centered approach at mean score of 3 and high quality interaction with peers and adults at score level of 2.9. The lowest two mean score level was the gadgets and computer roles in syllabus at mean score level of 2.0 and teacher centered teaching at 1.9 .

Parents are making homeschooling their favorite choice due to the increasing dissatisfaction about the general setting of their children's educational and the school setting itself (Edward, 2002). These have explained the trends of high level score of 4.3 for perception of homeschooler's parents in Malaysia who are in favor of their child who may not be ready for the new syllabus or curriculum in the educational system, followed by the dislike of the changes that had taken place in educational system by with score level of 4.23 , delaying the formal, structured instruction until their child is ready with mean score of 4.13 , too much homework burden in public school with mean score level of 3.96, the current syllabus in public school may cause poor level of academic achievement of their child with mean score of 3.9, the negative peer socialization associated with public schools may affect the growth of their child's character development with mean score of 3.9, the current curriculum or instruction in public schools is incompatible with their family beliefs or values with mean score of 3.63 , the lack of religious integration in syllabus offered by public schools with mean score 3.53 and the least favored resulting medium mean score level of 3.13 which most public schools use teacher-centered in teaching that it may impede students' interaction with each other. 
By interviewing the homeschooler's parents, the ideas of home school's key drivers were generated which were important as it is able to help to detect the main concern of homeschool in Malaysia. Table 1 tabulates the categories of drivers obtained in the interviews.

Table 1. Categories of drivers obtained in the interviews

\begin{tabular}{clll}
\hline No. & \multicolumn{1}{c}{ Categories of drivers } & Key drivers \\
\hline 1. & Social & $\bullet$ & Social problem \\
& & $\bullet$ & Parent involvement decison \\
& & $\bullet$ & Trust and confidence \\
\hline 2. & Technological & $\bullet$ & Technology oriented education \\
\hline 3. & Environmental & $\bullet$ & Green oriented education \\
\hline 4. & Economic & $\bullet$ & School's fees \\
\hline 5. & Political & $\bullet$ & Government policies \\
& & $\bullet$ & Firm in syllabus \\
& & $\bullet$ & Education syllabus \\
& & $\bullet$ & Government intervention \\
\hline 6. & Values & $\bullet$ Religious value \\
& & $\bullet$ Family values \\
\hline
\end{tabular}

Impact-uncertainty analysis (Figure 1) was used to determine the impacts and uncertainties in the determination of future of homeschooling in Malaysia. The selection of the highest degree of impact and highest degree of uncertainty are the key driver of Malaysia's homeschool future.

At this stage, the most uncertain and most impactful driver was identified. There are two key drivers selected as shown in the Figure 1. In this case, the education syllabus and the social problem handling are the key drivers which shaping the future of homeschool. They are highlighted in Table 1 which are D2 and D6.

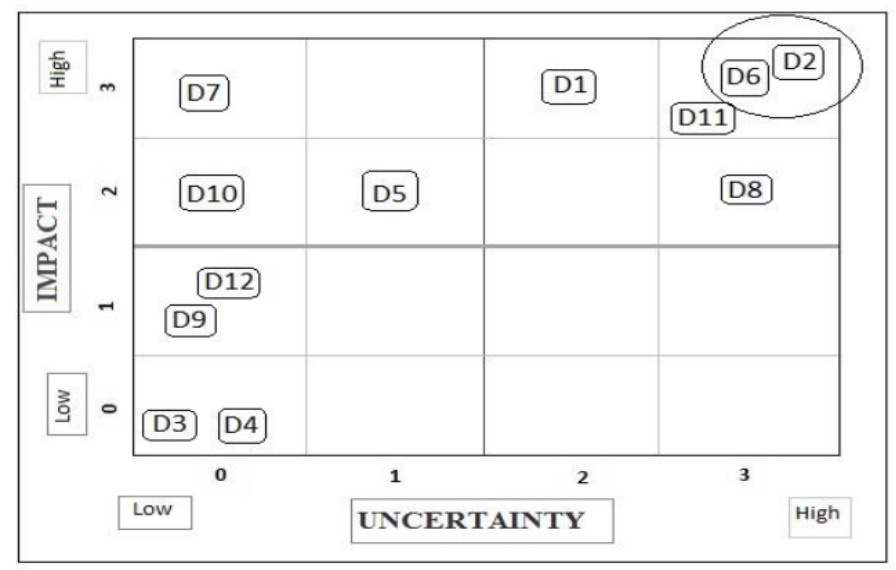

Figure 1. Impact-uncertainty analysis 
Table 2. Key drivers

\begin{tabular}{cl}
\hline Code & Drivers \\
\hline D1 & Religious value \\
D2 & Education syllabus \\
D3 & School's fees \\
D4 & Government intervention \\
D5 & Technology oriented education \\
D6 & Social problem handing \\
D7 & Green oriented education \\
D8 & Firm decision on syllabus \\
D 9 & Trust and confidence \\
D10 & Family values \\
D11 & Parent involvement decision \\
D12 & Government policies \\
\hline
\end{tabular}

As explained in the earlier sections, the lists of drivers above are the outcomes of analyzing the primary data collected.

Figure 2 shows the uncertainty axis analysis. The two drivers were put into the X-axis and Y-axis of the uncertain axis analysis.

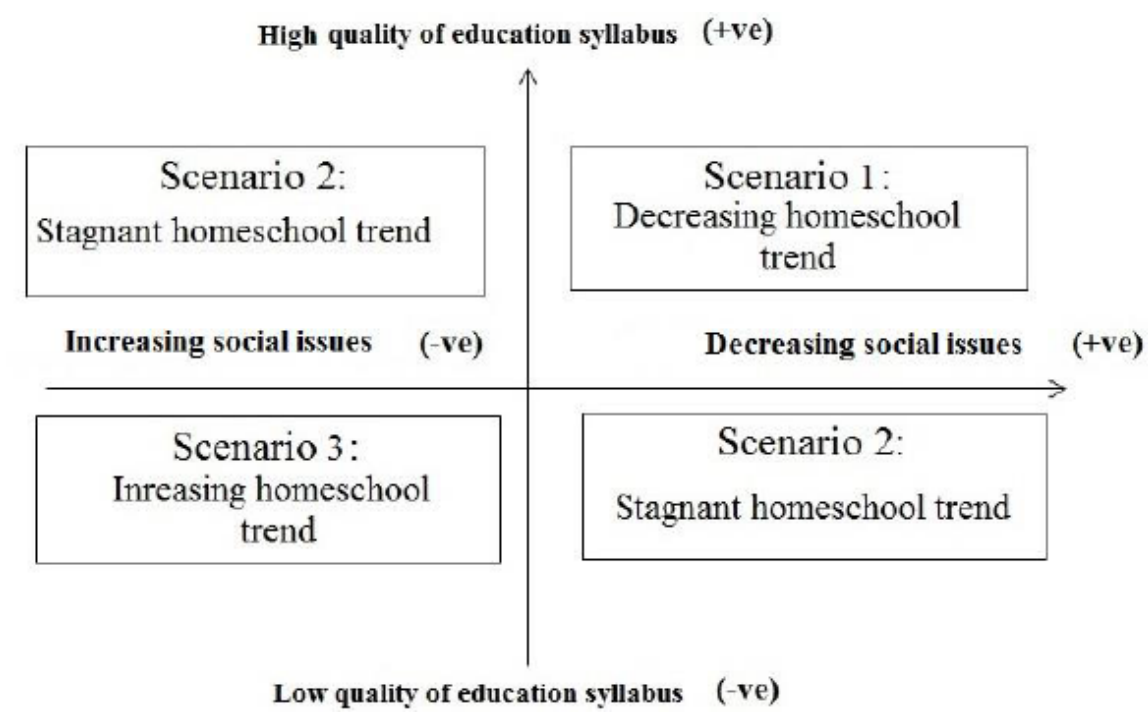

Figure 2. Uncertainty axis analysis

According to Soon and Chong (2013), homeschooling has been accepted by society in Malaysia even in the earlier days where policy governing homeschooling is not clear as yet. The number of parents who choose to homeschool has increased despite the enactment of the Compulsory and Free Education Act in the year 2002. As of 2012, it is estimated that almost 10,000 children in Malaysia have been homeschooled (Soon \& Chong, 2013). This had shown that the trend of homeschooling in Malaysia is on an increasing trend to the year 2025. Using the foresight methodology, the key drivers driving the trend can be generated through the various scenarios.

Scenario 1 indicates a decreasing trend of homeschool in Malaysia. Global education trends, social, economic and political dynamics are affecting Malaysian education system (Lee, 2015). Its government is continually upgrading and revising its national education system with that of other countries in-line with its 2020's vision of 
first class mind of establishing a scientific and progressive society. This implies that by 2025 , the quality of education should be better through the process of continual benchmarking. Malaysia Education Blueprint 2013 to 2025 is geared towards raising its international education standards in-line with the Government's aspiration of better preparing Malaysia's children for the needs of the 21st century, and increased public and parental expectations of education policy. Social issues about students faced are amongst the hot issues fiercely debated at Malaysia's Parliament. The Malaysian educational system is a national hot topic discussed at public forum as well. Should the government takes serious affirmative actions in transforming the system, focus on student's mental development, instilling and inspire the motivation of the correct social norms among students, the perception of parents on social ills among students issue will not arise and this would lead to a decline of parents opting for homeschool.

Scenario 2 shows a stagnant trend of homeschool in Malaysia. There are two different circumstances in this scenario. One is the high quality of education syllabus but poor in handling social problems. The other one is with low quality of syllabus but good at handling social problems. Both circumstances would create an equilibrium point of perception and create the option for parents opting to homeschool their children instead of sending to mainstream's schools. Therefore, in this case the Malaysia's homeschool trend would be in a stagnant situation or remain constant in its growth rate to the year 2025 .

Scenario 3 indicates an increasing trend of homeschooling in Malaysia. The impression of parents of mainstream's school becomes worst which widen the option of homeschooling as not just an alternative to education but also can become a common and popular choice for parents to decide. In this case, by the year 2025 Malaysia will endure a rising trend of homeschooling children.

\section{Discussion, Conclusion and Research Recommendation}

The first objective is achieved through the quantitative approach through the survey carried out. This finding is crucial as it is first step of foresight to know the current situation. Overall, the study revealed that the current trend of homeschooler's parents could be described through the characteristics that would suit a homeschooler's parents in Malaysia as the other past researches done were outside of Malaysia. Thus the classification that matches the criteria made homeschooling possible in Malaysia. As the research that creates a common of profile of parents that homeschool in Malaysia is of non-existent, it is important to create and classify these profiles by gathering the demographic data of these parents. The result shows that the profile of parents who homeschool their child in Malaysia are aged of between 36 to 45, had a Master degree living in an urban area with the total monthly income of husband and wife combined in a range of RM8001 to RM10000. This result was generated by averaging the parents' feedback from the responses obtained through the survey questionnaire. Malaysian homeschooler's parents showed a trend indicating that parents play a central role. This is indicated by the highest mean score on trend was 4.4 on a scale of 1 to 5 points. It supported the findings from studies on diverse groups of elementary and middle school students that role activity beliefs influence parents' decisions about becoming and being involved in their children's education involvement (e.g. Chrispeels \& Rivero, 2001; Drummond \& Stipek, 2004; Grolnick et al., 1997; Hoover-Dempsey et al., 2005; Sheldon, 2002). Green and Hoover-Dempsey (2007), for example, reported that most homeschool parents had particularly strong role activity beliefs related to involvement in their children's education. The trend of homeschooling styles and syllabus shows that Malaysian homeschool parents are using ideologues and according to Van Halen ideologues can be simplified as heaven based or religion based (Van Galen, 1988). The score of 3.8 supported the argument that religious beliefs is very well integrated in the parents' type of syllabus of homeschooling their children. Flexibility to suit individual need for the child was scored at a mean score 3.73. This correspond to the idea of building or nurturing the children to be their true self rather than letting the public school rank and standardize the children which let the parent worries as they feel traditional schools fail to encourage independent thinking as described by Franzosa (1991) and could stifle the children's creativity and growth as suggested by Gibbs (1994)..

Second objective is achieved through quantitative approach. In Malaysia, homeschooling exist in line with its act and policy. The greatest contributor of the homeschooling factor is the National system of Malaysia itself. It is the same like the homeschooling situation and conditions in China, where there is homeschooling academic freedom with the government still holding the authority in education. This raises skepticism to the future of homeschooling in China (Michael, 2008). The result of this study showed out of the 30 parents responding to the survey, $18(60 \%)$ of them relate that they are increasing not satisfied concerning their children's educational setting in the country. Parents do not like the frequent changes in the educational system. Among the reasons are, their child may not be ready for the new syllabus in the educational system, they desired to delay the formal, structured instruction until their child is ready, too much burden on homework at public schools, suspecting that the current syllabus in public schools may cause poor level of academic achievement in their child, the current 
curriculum or instruction in public schools is incompatible with the family beliefs or values or lack of religious integration in syllabus offered by public schools. Thus, as suggested by Edward (2002), homeschooling becomes one of the favorite choices among parents. The driver of homeschooling was recognized by the listing of current items which derived by the social, technology, economy, environment and values factor (STEEPV) analysis. From the inference of the data, 12 drivers were found and analyzed using impact-uncertainty analysis. The results of impact-uncertainty analysis indicated two key drivers of change of homeschooling in Malaysia. These are the education syllabus in Malaysia and social issues among students. To further understand the impact of the key drivers of change for the future of homeschool, the uncertainty axis analysis was done.

The first driver of change is the education syllabus in Malaysia itself. As highlighted by the interviewees, the syllabus offered in Malaysia are constantly changing and sometimes the changes made were drastic as reported in the news which result in confusion on how much their children could tolerate the pressure from such issue. A 2007 study conducted by Green and Hoover-Demsey supported the dissatisfaction of parents with public schools' ability to teach core values such as character development, and approach to special needs.

The second driver of change is the social issues among students and it involves many sides, such as the Ministry of Education or the government and teachers. The social problems nowadays could be described as critical as many incidents happened both in and out of school period and this terrifies a lot of parents as to them, the problem seems to be out of hand and not being handled properly.

The third objective is achieved through foresight methodologies which is scenario building. It involved applying drivers of change in the second finding into impact-uncertainty analysis, uncertainty axis analysis, scenario writing and scenario review. Three future possibilities were revealed: Scenario 1: Decreased homeschool trend; Scenario 2: Stagnant homeschool trend; and Scenario 3: Increased homeschool trend. The scenario depicts that the homeschool trend would increase due to the fact that parents lost the trust and confidence in the national education from an increase of unhandled social problems and the syllabus that the parents have lost interest in sending their children to the mainstream's schools. This is a loss to the government as billions of ringgit spent on infrastructure and training the teachers besides causing negative image to the current education system if it is not handled well.

Future study should focus on impact oriented areas and especially on engagement with stakeholders as there is lacking of studies on the impact of performance of homeschoolers and its engagement as compared with the mainstream's school students by academic performance.

Homeschooling is not new. The practice of homeschooling existed in various form and comes in formal and informal manner. Home schooling may not be for everyone. However, it is ideal for some families. Globally, homeschool is on a growing trend. It seems that Malaysian parents are adapting to the global changing trend. This is reflected in the result of this study which shown that the tendency of parents homeschooling their children is on an increasing homeschooling trend and in a way is following the trend of the developed countries like UK and US. Home schooling offers an alternative for parent believing that the current formal school system is not suitable for their child. Like the formal education system, it has its pros and cons too. Thus, it is not for everyone. Parent who are depends on two incomes will not be able to handle homeschooling, lacking of structure and proper syllabus and ability to customize the education plan for homeschooling could be another issue, the teaching materials could be tough for parent due to the fact that teacher has to go for formal training and qualified before they are allowed to teach in a formal school system. Homeschooling requires consistent dedication of the parent and in this case, parent must have their time committed to be able to deliver an adequate programme for the grade needed for their children. In certain cases, it could be multiple grades or levels of teaching. Homeschooling is thus complex in the urbanized society, as there are controversial issues and it may not offer a solution for the future.

A systematic implementation of education system is key to the future of a Country. Malaysia has enacted the Compulsory and Freedom Education Act in 2002. National policy maker has been restructuring and addressing the needs of children in the formal education system. Policy maker could regulate on the implementation of the act and give a chance of supervised homeschooling with performance indictor studies to determine the relevancy level of homeschooling in Malaysia so that it will create a win-win situation for the government and parents, which should be benefiting solely on the children's future. It is envisaged that formal criteria need to be setup for parent in home-schooling and only that these criteria are met, parents are allowed to homeschool their children. Latest OECD report has mentioned that the Country's top performance schools of aged 15 years old in the cities can compete with international peers in the British cities in the Programme for International Student Assessment (PISA). This point to the fact that it is important that the policy maker needs to be willing to engage with all 
stakeholders and parents for the development and management the education blueprint to raise the standard and quality of a successful school system and in this, developing curriculum that reflect the interests of students or what they need to survive and the needs of the nation.

This study has provided the foundation of the alternative of mainstreams schools which is homeschooling their children in Malaysia. The common factors of leading to homeschooling in Malaysia are that parents have no faith in the current education syllabus, religious belief integrated syllabus and flexibility of syllabus in homeschooling. It also found that the education syllabus in Malaysia and the social issues among students are the two key drivers of homeschool in Malaysia. From these two drivers of change, the current situation would have 3 possible future scenarios: Scenario 1: Decreasing trend; Scenario 2: Stagnant trend; and Scenario 3: Increasing trend. The journey of quality education management never ends. Quality management evolves and the future will be presented a different scenario through its journey of adding relevant and discarding irrelevant practices (Kim-Soon, 2012) to provide Malaysia a strategic education blueprint that is sensible, wholesome and appropriate to suit its stakeholders and the nation. In a nutshell, more effort and views should be paid in improving the overall of education in Malaysia. In this study, discussion were made and relevant recommendations has been provided through the derived foresighted Scenarios.

\section{Acknowledgements}

This research project is supported by Universiti Tun Hussein Onn Malaysia UTHM) through its Grant Number C043 to Dr. Ng Kim-Soon. This work is also done in collaboration with MIGHT on the use of STEEPV methodology propagated by MIGHT. The authors wish to thank the respondents who were interviewed and their willingness of sharing their experiences, time and patience for participating in this project.

\section{References}

Aurini, J., \& Davies, S. (2005). Choice without markets: Homeschooling in the context of private education. British Journal of Sociology of Education, 26(4), 461-474. http://dx.doi.org/10.1080/01425690500199834

Bajunid, I. (2002). Changing mindsets: Lifelong learning for all. Presentation at the International Conference on Lifelong Learning, 13-15 May 2002, Kuala Lumpur.

Basham, P. (2001). Home-schooling: From the extreme to the mainstream. Public Policy Sources, 51, 3-18.

Basham, P., Merrifield, J., \& Hepburn, C. R. (2007). Home schooling: From the extreme to the mainstream (2nd ed.). Vancouver, BC, Canada: The Fraser Institute. Retrieved from http://www.fraserinstitute.org/commerce.web/product_files/Homeschooling2007.pdf

Bielick, S., Chandler, K., \& Broughman, S. P. (2001). Homeschooling in the United States: 1999. Education Statistics Quarterly, 3(3), 1-12.

Boschee, B. F., \& Boschee, F. (2011). A Profile of Homeschooling: Why do South Dakota Parents Homeschool? Journal of School Choice, 5(3), 281-299.

Chrispeels, J., \& Rivero, E. (2001). Engaging Latino families for student success: How parent education can reshape parents' sense of place in the education of their children. Peabody Journal of Education, 76, 119-169. http://dx.doi.org/10.1207/S15327930pje7602_7

Collom, E. (2005). The ins and outs of homeschooling: The determinants of parental motivations and student achievement. Education and Urban Society, 37(3), 307-335. http://dx.doi.org/10.1177/0013124504274190

Drummond, K. V., \& Stipek, D. (2004). Low-income parents' beliefs about their role in children's academic learning. Elementary School Journal, 104, 197-213. http://dx.doi.org/10.1086/499749

Edward, B. S. (2002). Homeschooling: A comprehensive study of practice in Delaware and the Milford school district (Doctoral dissertation, University of Delaware).

Franzosa, S. (1991). The best and wisest parent: A critique of John Holt's philosophy of education. In Van Galen (Ed.), Home Schooling; Political, Historical, and Pedagogical Perspectives (pp. 121-135). Norwood, NJ: Ablex Publishing.

Gibbs, N. (1994). Home sweet school: Seeking excellence, isolation, or just extra "family time," more and more parents are doing the teaching themselves. Time, 144(18), 62-63.

Green, C. L., \& Hoover-Dempsey, K. V. (2007). Why Do Parents Homeschool? A Systematic Examination of Parental Involvement. Education and Urban Society, 39(2), 264-285. http://dx.doi.org/10.1177/0013124506294862 
Grolnick, W. S., Benjet, C., Kurowski, C. O., \& Apostoleris, N. H. (1997). Predictors of parental involvement in children's schooling. Journal of Educational Psychology, 89(3), 538-548. http://dx.doi.org/10.1037/0022-0663.89.3.538

Haugh, B. (2014). Hesitation to Resolution: Our Homeschooling Narrative. Journal of Unschooling and Alternative Learning, 8(16).

He, W. H. (2012). Deep analysis on homeschooling in China: A comparison between China and America. Zhejiang Social Sciences, 11.

Holt, J. (1981). Teach your own: A hopeful path for education. New York, NY: Delacorte Press.

Hoover-Dempsey, K. V., Walker, J. M. T., Sandler, H. M., Whetsel, D., Green, C. L., Wilkins, A. S., \& Closson, K. E. (2005). Why do parents become involved? Research findings and implications. Elementary School Journal, 106, 105-130. http://dx.doi.org/10.1086/499194

Ice, C. L., \& Hoover-Dempsey, K. V. (2011). Linking Parental Motivations for Involvement and Student Proximal Achievement Outcomes in Homeschooling and Public Schooling Settings. Education and Urban Society, 43, 339. http://dx.doi.org/10.1177/0013124510380418

Kim-Soon, N. (2012). Quality Management System and Practices. In K.-S, Ng (Ed.), Quality Management and Practices, INTECH, Croatia.

Kim-Soon, N., Anwar, J., Razzaly, W., \& Rahman, A. (2014). Drivers of Change of University and Industry Collaboration from the Perspective of the Food Manufacturers: A Foresight Case. Proceeding of the 23rd International Business Information Management Association (IBIMA) Conference, Spain, May 13-14, 2014, (pp. 335-348). http://dx.doi.org/10.1109/ICMIT.2014.6942419

Kunzman, R., \& Gaither, M. (2013). Homeschooling: A Comprehensive Survey of the Research. The Journal of Educational Alternatives, 2(1), 4-59.

Lee, M. N. N. (2015). Higher Education in Malaysia: National Strategies and Innovative Practices, Mass Higher Education Development in East Asia. Knowledge Studies in Higher Education, 2, 105-118. http://dx.doi.org/10.1007/978-3-319-12673-9_6

Lines, P. M. (1995). Home Schooling, ERIC Digest, No. 95. ERIC Clearinghouse on Educational Management Eugene, ERIC Number: ED381849 OR. Retrieved from http://www.ericdigests.org/1996-1/home.htm

Lines, P. M. (2000). When homeschoolers go to school: A partnership between families and schools. Peabody Journal of Education, 75, 159-186. http://dx.doi.org/10.1080/0161956X.2000.9681940

Lyman, I. (1998). Homeschooling: Back to the future? Cato Policy Analysis, 294.

MacFarquhar, N. (2008). Resolute or fearful, many Muslims turn to homeschooling. New York Times, 26 March, p. A14.

Michael, H. R. (2008). Chinese Graduate Students' Perspectives on Home Schooling. National Home Education Research Institute, 17(3), 7-15.

Princiotta, D., Bielick, S., \& Chapman, C. (2004). 1.1 million homeschooled students in the United States in 2003. Issue Brief (NCES 2004-1115).

Rajamony, E. J. A. Y. (2008). The Malaysian experience in home schooling (Ph.D, Universiti Putra Malaysia, Kuala Lumpur).

Ray, B. D. (1997). Home education across the United States: Family characteristics, student achievement, and other topics. Purcellville, VA: HSLDA Publications.

Ray, B. D. (2000). Home-schooling: The ameliorator of negative influences on learning? Peabody Journal of Education, 75, 71-106. http://dx.doi.org/10.1080/0161956X.2000.9681936

Ray, B. D. (2009). Homeschool progress report 2009: Academic achievement and demographics. Retrieved from http://www.hslda.org/docs/study/ray2009/2009_Ray_StudyFINAL.pdf

Ray, B. D. (2011). 2.04 million homeschool students in the United States in 2010. Research Paper, National Home Education Research Institute, Salem.

Ross, C. J. (2010). Fundamentalist challenges to core democratic values: Exit and homeschooling. William and Mary Bill of Rights Journal, 18, 991-1014. Retrieved from http://scholarship.law.wm.edu/wmborj/vol18/iss4/8 
Rudner, L. M. (1999). Scholastic achievement and demographic characteristics of homeschool students in 1998. Educational Policy Analysis Archives, 7.

Russo, F. (1999). Home-school report card: Parents are teachers for a million kids, but does homeschooling work? Time, 154, C10.

Ryan, R. M., \& Deci, E. L. (2000). Self-determination theory and the facilitation of intrinsic motivation, social development, and well-being. American Psychologist, 55, 68-78, http://dx.doi.org/10.1037/0003-066X.55.1.68.

Sheldon, S. B. (2002). Parents' social networks and beliefs as predictors of parent involvement. Elementary School Journal, 102, 301-316.

Soon, K. V., \& Chong, W. L. (2013). Homeschooling: Introduction and a Perspective. Kertas Kerja dibentangkan di Bengkel Pendidikan Alternatif Kebangsaan, Anjuran Fakulti Pendidikan Universiti Malaya, 21-22 Mac, 2013, Kuala Lumpur.

Stevens, M. L. (2001). Kingdom of children: Culture and controversy in the homeschooling movement. Princeton, NJ: Princeton University Press.

Van Galen, J. (1988). Ideology, curriculum, and pedagogy in home education. Education and Urban Society, 21, 52-68. ERIC Number: EJ384824.

Walker, J. M. T., Ice, C. L., Hoover-Dempsey, K. V., \& Sandler, H. M. (2011). Latino Parents' Motivations for Involvement in Their Children's Schooling: An Exploratory Study. The Elementary School Journal, 111(3), 409-429. Retrieved from http://www.jstor.org/stable/10.1086/657653

Zhao, J., \& Badzis, M. (2014). Parents' Perspectives on Homeschooling in Chinese Mainland. International Journal of Learning and Teaching, 1(1), 15-18. http://dx.doi.org/10.12720/ijlt.1.1.15-18

\section{Copyrights}

Copyright for this article is retained by the author(s), with first publication rights granted to the journal.

This is an open-access article distributed under the terms and conditions of the Creative Commons Attribution license (http://creativecommons.org/licenses/by/3.0/). 